\title{
DEVELOPMENT OF ADULT EDUCATION IN EUROPE AND IN THE CONTEXT OF KNOWLES' STUDY
}

\begin{abstract}
The presented article touches upon the idea of adult education history in Europe. It highlights the main programmes and events, which were a great contribution to the development of lifelong learning. At ancient times, adult students considered to be the prominent audience at philosophical lectures of immortal minds. After the period of industrialization and social equality, primary and secondary education became the priority topics of governmental policies. Only after WWII there appeared a need for reviewing or upgrading the already existed knowledge, nothing to say about the late 2000s with the immigration realia and population aging, adult learning takes over the prior importance in Europe. Malcolm S. Knowles was one of the scholars who had been investigating the domain in the mid 1960s and created the theoretical background for further researches. His attitude and vision of adult education process were the predictors of a new adragogical age in Europe, where student took a new central role in the education process, was encouraged to hold responsibility for the most suitable methods, that would match up with their goals, possibilities, intentions and timing. In modern society, there exists an urgent need for changes in the approaches to teaching adults, for individual work that is more appropriate for age and ensures usage of personal experience. The maturity dimension scheme presented by M. Knowles brings understanding of adult psychological inclinations, behaviour and goals that might help an andragogue to decide on methods chosen for achieving educational results. Clear determination of notions should explain and help to avoid misunderstandings on "whom should we consider an adult?" Historical approach will help to create a complex adult education development picture and motivate a researcher for further investigations.

Keywords: adult education, andragogue, upgrading, personal development, professional skills, social roles, world changes, mobility, technological progress.
\end{abstract}

\section{INTRODUCTION}

Adult education takes a crucial idea in the education management structure these days. It involves participation of both business sector and government policy. It ensures the social protection of individuals who face burdens of professional inappropriateness, lack of foreign literacy, economic struggles and problems of self-realization. Government officials of European countries are making up strategies for adult education promotion, stressing the importance of digital accessibility of informational content as a bulk of public awareness of the courses proposed to adult students and their financing (European Commission, 2012; Eurostat Statistics Explained, 2015).

THE AIM OF THE STUDY

The aim of study is to create unified informative data, which would give possibility to understand the process of adult education development, chronologically systematize terms and concepts used in theory. 


\section{THEORETICAL FRAMEWORK AND RESEARCH METHODS}

Theoretical framework of the research has been developed on the basis of scientific works by European scholars such as R. Havighurst (1970), J. Holford \& M. Milana (2014), O. Houle (1973), L. Pepin (2006), P. Rassmussen (2014), E. Thorndike (1928), A. Tough (1979) et al.

Research methods such as comparison (Europe and the USA); theoretical analysis (M. Knowles' terminology in adult education); induction and deduction (the specifics of education development in the $20^{\text {th }}$ century) have been used to highlight and explain the most significant periods in adult education theory at formative stages.

\section{RESULTS}

Tracing back into history of humanity one may remember the ancient philosophers (Alexamenus of Teos, Plato, Aristotle, Plutarch, Pythagoras, Socrates, Seneca, Cicero etc.) who undertook the roles of pedagogues while sharing their revolutionary ideas with mankind. They did not teach but develop the students' conscious and brought changes into the society. These were the first andragogues, who were passing the knowledge of world to adults trying to guess the sense of life. Taking into account the above-mentioned names, many state it was Europe where adult education first started.

Later adult education was realized through apprenticeship, when a person would learn art or trade by working for a skilled master for a certain number of years. Masters also often taught their apprentices how to read, write and even more. One may remember the popular fiction "The Physician" (1986) by N. Gordon - being an adult, main hero decides to be a pupil of an acknowledged doctor.

Some of the first formalized adult education institutions were correspondence schools. In Great Britain, France, Germany, correspondence education developed and quickly spread during the mid $19^{\text {th }}$ century. For example, in 1840 the English educator Sir Isaac Pitman taught shorthand by mail (New World Encyclopedia, 2016). Later, members of lyceums held discussions as well as attended lectures and debates. There had been created traveling groups that went from town to town presenting lectures.

At the end of World War II, many European governments set up programmes for ex-soldiers wanting to obtain professional skills. Language skills were considered a prestige that marked the elite who took the role of ambassadors for peaceful dialogue between nations. Consequently, education stopped being the privilege of the young or wealthy. There appeared community colleges, vocational colleges and returning student oriented programs. Now, at the official level, governments recognized the importance of adult education and funded programs for literacy, vocational skills and adults seeking to master new professions. Scattered groups responsible for adult education sprang up in Europe during the Industrial Revolution. Lectures and intellectual associations became popular in the early $20^{\text {th }}$ century and from these developed social movements and the recognition that education was incredibly important to the benefit of society (New World Encyclopedia, 2016).

Then, years of relative stability in social roles, brought a decline in the domain as much attention was paid to primary, secondary and higher education, which caused knowledge blockade for middle-aged population targeting at upgrading or obtaining new skills. P. Rasmussen (2014) even stated that adult learning became an element in the educational policies of Europe relatively late, but during the last decade lifelong learning has become much more important.

The studies on adult learning started to appear after World War II. There was a clear understanding of the fact that methodological techniques used before were out of date, 
did not match with the demands of time. To prove the necessity of adult education support, M. Knowles (1980) presented the scheme of changes describing the frequency of change one must experience during life in the $20^{\text {th }}$ century, it showed that modern individual faced 4 times more social changes than people living before. It proved we should adjust our skills and knowledge to the "wind of change" (p. 41). Today, many homeless and unemployed people are the result of professional inappropriateness, inability to correspond to the needs of modern society. That is why there should be a complex system of support for selfdevelopment of such citizens.

In the 1980s, there started international cooperation in this field. In 1974, there was established the Cedefop centre with the mission to collect and exchange information on national systems of vocational training and prepare a harmonization of training levels (Rassmussen, 2014).

Educational policy was generally seen in the context of the severe youth unemployment in most of Europe. Vocational preparation, guidance and basic skills were seen as key elements in policies to reduce youth unemployment. The European Social Fund was widely used for such measures; in 1984, $75 \%$ of its funds went to projects to generate skills and employment for young people (Pepin, 2006).

Only in 1992 that Maastricht Treaty formally included education as an area of collaboration. Despite the growing number of programmes targeting vocational training of students, lack of informational data made it a very slow and ineffective process until the 2000 's, when digital materials and Internet made it possible to search for necessary information in every corner of the world (Rassmussen, 2014).

M. Knowles himself dates back the creation of English AE in 1926 when American Association for Adult Education was founded. Many organizations in the field of adult education have been functioning for more than 50 years, but became well-known in the era of "language barrier lost", when international cooperation is possible. The European Bureau for Adult Education was founded in 1953 by representatives from a number of European countries. ESREA is a European scientific society. It was established in 1991 to provide a European-wide forum for all researchers engaged in research on adult education and learning and to promote and disseminate theoretical and empirical research in the field.

The stress was made on the necessity of constant upgrade of professional skills, stating that society changes rapidly and the process continues to speed up. Working on the development of adult education theory, M. Knowles (1980) mentioned that each decade in adult education was marked by new approaches, attitudes and understanding, which brought changes into theoretical framework, organizational structure, personnel, clientele, methods, techniques and materials. Adult educators who used the practices in the 1970s that they had learned a decade before were ineffective and archaic. "Modern is thus very temporary state", stated the scholar (p. 18).

M. Knowles had predicted changes that happened in the 1980-90s. The purpose of education experienced crucial changes. Before this period, AD (Adult Education) was aimed at "educated man", that was justified by the era of slow changes, when new technology and knowledge appeared very gradually, $\mathrm{AE}$ was considered mainly for elite leisured class, but in the era of technological revolution, social policy of equality, this was no longer acceptable. The mission of education targeted a "competent person" who was able to apply new knowledge under changing conditions. As a result, there appeared a notion of "competency-based education". The shift of focus from teaching to learning, selfdirection of a student rather than a reaction to teaching methods was studied by J. Bruner 
(1966) and A. Tough (1979). There appeared the term "lifelong learning" supported by the idea of orientation to education during life. New possibilities to deliver knowledge to a student caused the discussion of nontraditional study, external degree, multimedia learning system, community education, learning communities, educational agencies, learning networks.

The necessity to describe theory of AD motivated M. Knowles (1980) to the explanation of core terminology, where the first place took the term "adult" itself. Along the decades there existed different points of view on "Whom should we call an adult?" But there are two-aspect criteria described by the scholar: 1) who behaves like adult, and performs relevant social roles; 2) who has an adult self-concept (Knowles, 1980). For a long time, we regarded the education process only in the context of childhood and youth. Keeping to this criterion, we observed many adults who experienced cultural shock starting part-time study and being treated like children. M. Knowles (1980) stated that those highschool students who had household duties of an adult or worked at part-time jobs performed adult social roles and should be treated like adults as well.

What about the educators? There are many trainers, coaches, instructors, leaders, supervisors who are in charge of educating the adults, though very few of them work in the field professionally, they do not share the methodology of adults teaching, thus they have lack of a result. One may imagine how far could we have passed in case there was a basis for consulting in adult education.

Helping the learner diagnose their needs, planning the activities that would produce the desired effect, creating the conditions, selecting the most effective methods, providing human and material resources that will help to learn, measure the outcomes of the learning experience, to satisfy needs and goals had been described by M. Knowles (1980) as the main andragogue's activity (p. 49). Presenting the enumeration of maturity dimensions the scholar indicated methods' choice made by those teaching adults: from dependence towards autonomy; from passivity towards activity; from subjectivity towards objectivity; from ignorance towards enlightenment; from small abilities towards large abilities; from few responsibilities towards many responsibilities; from narrow interests towards broad interests; from selfishness towards altruism; from self-rejection towards selfacceptance; from amorphous self-identity towards integrated self-identity; from focus on particulars towards focus on principles; from superficial concerns towards deep concerns; from imitation towards originality; from the need for certainty towards the tolerance for ambiguity; from impulsiveness towards rationality.

The psychological definition of adulthood is that of the period when individuals perceive themselves as being self-directed, which is opposite to the childhood conscious which tends to be protected and directed by parents, teachers. Moreover, the tendency of being governed stays with adults the minute they enter the process called "education". They preserve the habit of being directed, though psychologically would show better results applying creative learning method. The last would match up perfectly with their age characteristics, tendencies and possibilities. While being totally under control lessens perception activity, memorizing, reproduction. Adults love self-government, though react passively to authority.

There had been highlighted several important aspects of organizing an adult classroom: learning climate; diagnosis of needs; process planning; education of learning; orientation of educators; organization of the curriculum; design of learning experience.

R. Havighurst (1970) illustrated three stages of maturity during adulthood: early adulthood (18-30); middle age (30-55); later maturity (55 and over). Analyzing these one 
may come to personal conclusions on the educational goals an individual may have at every stage. Time is something, which is a very important issue of adult education. Being a pupil a person has a prolonged period for study expecting to enter university, college and institute. Being a student one presupposes where they would be able to apply their knowledge. Being a mature a person is time-pressed because their study is being conducted under the need of a current life situation. They wish to see immediate results, something that is hard to fulfill, especially when we speak of acquiring foreign language skills.

In his work on adult education, M. Knowles (1980) stated there are three adragogical approaches when conducting adults' teaching: a) adults can learn (in 1927 there was presented a report by L. Thorndike which scientifically proved that the ability to learn declined very slowly after age of 20 , before that time many believed that after their 20 s people were hard to learn, only 1 percent of the group showed study problematics after age of 25, and it was in learning speed but not in intellectual power) (p. 55); the track downs of learning activity were caused by the reasons of systematic education gap; psychological changes like decline of visual acuity, reduction of reaction speed, lowering of energy level which could be easily compensated by slower pace, louder sound, larger printing; b) internal character of learning which means that much attention should be paid to interaction, dialogue, creation of self-concept when a student realizes its inner motivation for study; form their own methodology and techniques for material perception; "The truly artistic teachers of adults perceive the locus of responsibility for learning to be in the learner" (Knowles, 1980, p. 56); c) conditions of learning and principles of teaching. Under the term "condition" we do not mean physical aspect of the education process, but its inner state. The most important from this point of view would be "a need to learn", without this it will not be possible to create the power of motivation, energy to fulfill the activity. The second condition is atmosphere in class, openness, acceptance of differences, toleration of momentarily failures, physical relevance (appropriate visual tools). Third comes the feeling of commitment and as a result the sense of progress. Teaching principles should include such options as encouraging to use new possibilities; helping to change self-perception and behaviour; diagnosing mistakes; proving physical conditions; demonstrating respect to students' experience; creating friendly atmosphere; formulating learning objectives; supporting the students with one's own experience; helping to organize themselves (project groups; learning teams etc.); adjusting to the level understandable to adult students; helping to integrate new knowledge in everyday life.

Under the above-mentioned conditions, the mission of a teacher in a field had changed dramatically. Being not separated from children and youth education, adult teacher took the role of a commander in the class, choosing the study methods, which at times turned out to be ineffective. Realizing the maturity dimension presented by M. Knowles (1980) and adults' potential based on the already presented experience, teachers started to transform into the supervisors who directed and advised but never took the decision about what method is better and which is bad. A teacher turned into a helper, guide, encourager, consultant but not a transmitter, disciplinarian, judge and authority. In the 1980s, there appeared new titles given to those teaching adults: "change agents" or "helping roles", which sound very aptly in the modern world of constant change (Knowles, 1980, p. 37).

The idea of the "andragogue" appeared in the 1930s of the past century when Journal of Adult Education published the first interviews by those teaching adults though lacking professional terminology (Knowles, 1980, p. 41).

Informal adult education was the first published book on "continuing learning" by M. Knowles where he enlisted the main principles of education without unified theory. 
Internal processes on adult learning were presented in the 1960 s with a book of Cyril O'Houle called The Inquiring mind. C. Houle highlighted 3 motivation categories, which enforced adult students to learning: goal-oriented; activity-oriented; learning-oriented (Houle, 1973). Later, A. Tough extended the theory to the understanding of individual work of a student (Tough, 1923). The main question of his scientific research was "How do adults learn naturally - without being taught", without a teacher. Much information was taken from the related disciplines - clinical psychology, developmental psychology, gerontology, sociology, anthropology.

During this period there appeared a term "andragogue" to distinguish between classical pedagogy and teaching the adults, which is based on Greek word "aner" (with the stem andr-), meaning man, not boy or adult. There established the common sense of andragogy as science of helping adults learn, in contrast to pedagogy as a science of teaching the children. Comparing pedagogy and andragogy there are three main different approaches to diversification: the role of learner's experience; readiness to learn; orientation to learning (Knowles, 1980, p. 43).

\section{CONCLUSIONS}

Nowadays, there are many scholars who promote the idea of education for those in their adult age (A. Fejes from Linköping University, Sweden; J. Holford from University of Nottingham, United Kingdom; P. Rasmussen from Aalborg University, Denmark etc.) as the emotionally formed personality undertakes a higher degree of responsibility and motivation during study process, an individual is more mobile and flexible to the environmental changes due to the already presented experience of interchange and cofunctioning, adjusting to life realia (Milana, Holford, 2014). The first seminar on the History of Adult Education and Training in Europe was held in June 2009 at the University of Turku. 14 papers were presented by participants from 8 countries (Denmark, Finland, France, Germany, Hungary, Japan, Portugal and Sweden). Life course and learning in different contexts as well as various concepts of lifelong education and learning were presented and debated (European Seminar of Turku, 2009). Adult education is not about storing the already existing facts; it is about creation of new ones. M. Knowles (1980) himself believed that adragogical approach to study children and youth was a tendency of the then education, which would prepare the whole generation for a lifelong learning. He prepared reports for UNESCO "Toward a Model of a Lifelong Education" with his vision of promotion the idea and reasons of its importance.

The perspective of further investigation is the study of adult education theory in Europe and Ukraine in the $21^{\text {st }}$ century.

\section{REFERENCES}

1. Bruner, J. S. (1966). Towards a theory of instruction. Cambridge, Mass.: Harvard University Press.

2. Havighurst, R. (1970). Developmental tasks and education. New York: D. McKay Co.

3. Houle, C. O. (1973). The external degree. San Francisco: Jossey-Bass.

4. EUR-Lex. (2011). Communication from the Commission to the European Parliament. Retrieved from http://eur lex.europa.eu/legal content/EN/ALL/?uri=CELEX:52 $008 \mathrm{DC} 0425$. 
5. European Commission. (2012). Education and training. Supporting education and training in Europe and beyond. Retrieved from http://ec.europa.eu/education/ policy/adult-learning/adult_en.

6. European Seminar of Turku. (2009). Life course and learning in history: cultural, societal and individual perspectives on adult education and training in Europe. Retrieved from http://www.esrea.org/filarkiv/1.97761/CRTurku-VF.pdf.

7. Eurostat Statistics Explained. (2015). Adult learning statistics - characteristics of education and training. Retrieved from http://ec.europa.eu/eurostat/statisticsexplained/index.php/Main_Page.

8. Knowles, M. S. (1980). The modern practice of adult education. Retrieved from http://www.umsl.edu/ henschkej/articles/a_The_\%20Modern_P ractice_of_Adult_Education.pdf.

9. Milana, M., \& Holford, J. (2014). Adult education policy and the European Union. Theoretical and methodological perspectives. Rotterdam: Sense Publishers.

10. New World Encyclopedia. (2016). Adult Education. Retrieved from http://ww w.newworldencyclopedia.org/entry/Adult_education

11. Pépin, L. (2006). The history of European cooperation in education and training. Brussels: EU Publications Office.

12. Rasmussen, P. (2014). Adult learning policy in the European Commission. In M. Milana, \& J. Holford (Eds.), Adult education policy and the European Union: theoretical and methodological perspectives (Vol. 1, pp. 17-34). Rotterdam, Holland: Sense Publishers.

13. Thorndike, E. L. (1928). Adult learning. New York: Macmillan.

14. Tough, A. (1979). The adult's learning projects. Toronto: Ontario Institute for Studies in Education. 